\title{
A Report on a Long Term Research Program on the Bowman site in Arkansas
}

Duncan P. McKinnon

University of Central Arkansas

Follow this and additional works at: https://scholarworks.sfasu.edu/ita

Part of the American Material Culture Commons, Archaeological Anthropology Commons, Environmental Studies Commons, Other American Studies Commons, Other Arts and Humanities Commons, Other History of Art, Architecture, and Archaeology Commons, and the United States History Commons

Tell us how this article helped you.

This Article is brought to you for free and open access by the Center for Regional Heritage Research at SFA ScholarWorks. It has been accepted for inclusion in Index of Texas Archaeology: Open Access Gray Literature from the Lone Star State by an authorized editor of SFA ScholarWorks. For more information, please contact cdsscholarworks@sfasu.edu. 


\section{A Report on a Long Term Research Program on the Bowman site in Arkansas \\ Creative Commons License \\ (c) () () (9)}

This work is licensed under a Creative Commons Attribution-NonCommercial 4.0 International License 


\title{
Current Research:
}

\section{A Report on a Long Term Research Program on the Bowman site in Arkansas}

\author{
Duncan P. McKinnon \\ University of Central Arkansas
}

\begin{abstract}
The Bowman (3LR46) and Bowman/Wallace (3LR50) sites represent a Caddo multi-mound center on the Red River in Little River County, Arkansas (Figure 1). Southeastern researchers may recognize the site name from an engraved shell cup and several additional "SECC" objects found in Mound 2 (Phillips and Brown 1978:167-168; Hoffman 1970:173; see also Knight et al. 2001; Millan 2005). Hoffman (1970:167-168) provides a brief summary of digging at the sites and offers a proposed site organization of eight mounds (both burial and "temple mounds") surrounding a possible plaza area and at least three offmound cemeteries. Material collected from Mounds 1 and 2 and two off-mound cemeteries suggest Haley phase (ca. A.D. 1200-1400) occupations. Additionally, data from Mound 1 have the potential to "reveal a solid sequence of [Caddo] burial and mortuary artifact styles" beginning with the earliest Caddo occupations in the Red River region (Hoffman 1970:168-169, 173).
\end{abstract}

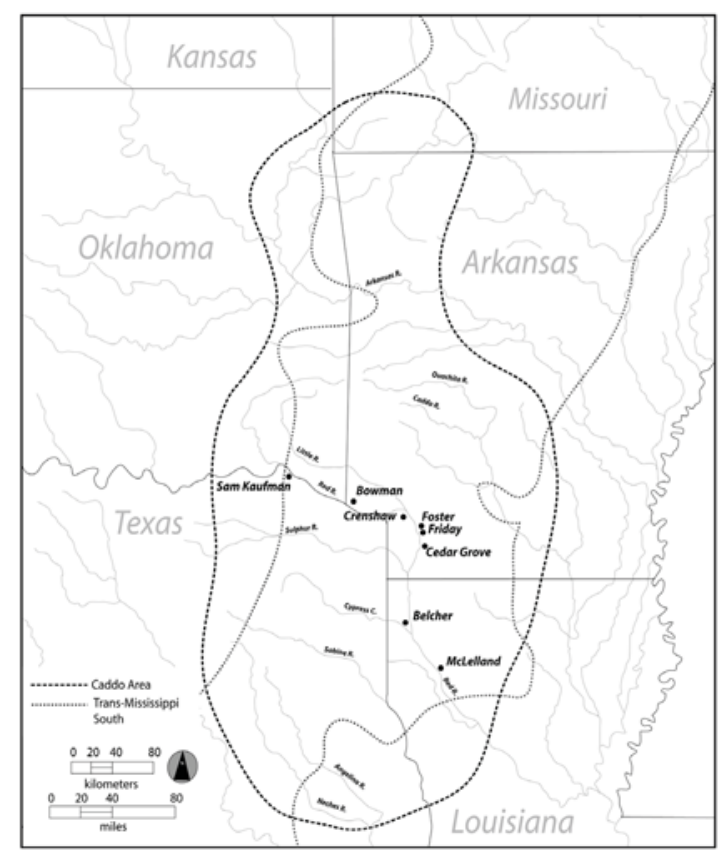

Figure 1. Location of Bowman and select sites in the Red River region.
Despite its importance as a likely center of exchange and influence, little empirical and systematic research has been conducted at the Bowman site. Over the last 70 years (at least), there are numerous accounts of pothunters digging at the site, various sketch maps of the contents of looted burials, amateur drawings of whole pots collected, and random inventories of vessels and other artifacts. Much of what we know about the site is from these activities. Today, collected material is scattered throughout museums and private collections. A synthesis of historical information about the site and the development of a research program is long overdue. In this light, I am in the beginning phases of a long-term research program to better understand the diachronic relationship of the Bowman occupations to contemporaneous sites in the region.

The first phase is to identify, organize, inventory, and synthesize collector notes and documentation, published summaries and discussions, and materials associated with the site. Much of this initial work will be integrated into teaching opportunities with University of Central Arkansas (UCA) students. Phase one is underway with the documentation of 31 fully or partially reconstructed vessels from unknown provenience and collected in the late 1960s (Figure 2).

Phase two will build upon this synthesis to evaluate and document the site using geophysical survey and topographic mapping to understand the nature and preservation of mounds and subsurface archeological deposits. This is an important step given the history of looting and potential destruction of archeological features. While looting has undoubtedly impacted the site, geophysical survey conducted on looted sites has been successful in recording the presence of undisturbed and interpretable cultural features (see McKinnon 2013; McKinnon et al. 2016). Phase three will work to integrate data from the first two phases and will also include low-impact field-testing in select areas depending on geophysical results and need for additional primary data.

Certainly, this is an endeavor that will take several years before a better understanding of the Bowman site can be realized. Yet, without a beginning there cannot be an end. 


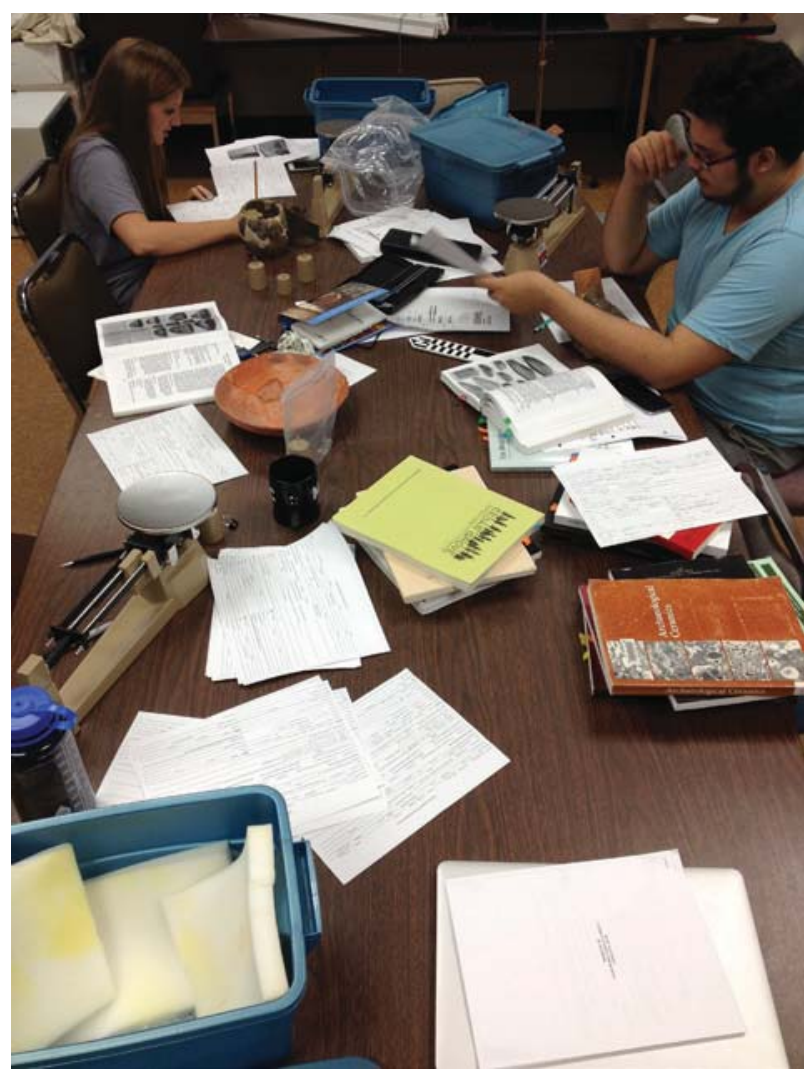

Figure 2. UCA students documenting reconstructed vessels from the Bowman site.

\section{References Cited}

Hoffman, Michael P.

1970 Archaeological and Historical Assessment of the Red River Basin in Arkansas. In Archeological and Historical Resources of the Red River Basin, edited by Hester A. Davis, pp. 137-194.

Research Series No. 1. Arkansas Archeological Survey, Fayetteville.
Knight, Vernon J. Jr., James A. Brown, and George E. Lankford

2001 On the Subject Matter of Southeastern Ceremonial Complex Art. Southeastern Archaeology 20:129141.

Millan, Brett J.

2005 The Southeastern Ceremonial Complex: The Evolution of a Concept. Master's Thesis, Department of Interdisciplinary Studies, University of Texas-Pan American.

McKinnon, Duncan P.

2013 Battle Mound: Exploring Space, Place, and History of a Red River Caddo Community in Southwest Arkansas. Ph.D. dissertation, Department of Anthropology, University of Arkansas, Fayetteville.

McKinnon, Duncan P., Jason L. King, Jane E. Buikstra, Taylor H. Thornton, and Jason T. Herrmann

2016 Returning to Kamp Mounds (11C12): Results from Geomagnetic Survey and High-Density Topographic Mapping in Calhoun County, Illinois. Midcontinental Journal of Archaeology 41(3):231254.

Phillips, Philip, and James A. Brown

1978-1984 Pre-Columbian Shell Engravings from the Craig Mound at Spiro, Oklahoma. 6 Vols. Peabody Museum Press, Cambridge. 